\title{
Effects of belowground resource use comlementarity on invasion of constructed grassland plant communities
}

\author{
Cynthia S. Brown · Kevin J. Rice
}

Received: 24 May 2008/Accepted: 27 July 2009/Published online: 12 August 2009

(C) The Author(s) 2009. This article is published with open access at Springerlink.com

\begin{abstract}
At two field sites that differed in fertility, we investigated how species richness, functional group diversity, and species composition of constructed plant communities influenced invasion. Grassland communities were constructed to be either functionally diverse or functionally simple based on belowground resource use patterns of constituent species. Communities were also constructed with different numbers of species (two or five) to examine interactions between species richness, functional diversity and invasion resistance. We hypothesized that communities with more complementary belowground resource use (i.e., more species rich and more functionally diverse communities) would be less easily invaded than communities with greater degrees of belowground resource use overlap. Two contrasting invasive species were
\end{abstract}

C. S. Brown $(\square)$

Department of Bioagricultural Sciences and Pest

Management, Colorado State University, Fort Collins, CO 80523, USA

e-mail: Cynthia.S.Brown@ColoState.edu

C. S. Brown

Graduate Degree Program in Ecology, Colorado State University, Fort Collins, CO 80523, USA

\section{K. J. Rice}

Department of Plant Sciences, University of California, Davis, CA 95616, USA

K. J. Rice

The Center for Population Biology, University

of California, Davis, CA 95616, USA introduced: an early-season, shallow rooting annual grass, Bromus hordeaceus (soft chess), and a lateseason, deep rooting annual forb, Centaurea solstitialis (yellow starthistle). Invader responses to species richness and functional diversity treatments differed between sites. In general, the more similar the patterns of belowground resource use between residents of the plant community and the invader, the poorer the invader's performance. Complementarity or overlap of resource use among species in the constructed communities appeared to affect invader success less than complementarity or overlap of resource use between the invader and the species present in the community.

Keywords Niche overlap - Resource partitioning · Functional diversity - Species richness .

Functional group - Bromus tectorum .

Centaurea solstitialis . Yellow starthistle .

Soft chess

\section{Abbreviations \\ ANOVA Analysis of variance}

\section{Introduction}

Early in the twentieth century, scientists began to investigate the characteristics of species and plant communities in search of mechanisms that influence plant invasions. Understanding these underlying mechanisms is critical for conservation of native 
biodiversity and for the restoration of disturbed habitats with plant communities that resist invasion by undesirable species. Suites of characteristics associated with invasive plants have been identified including high population growth rates, short life cycles, high allocation to reproduction, good dispersal, and flexible utilization of a variety of resources (Baker 1965; Orians 1984; Noble 1989; Roy 1990; Rejmánek 1996; Goodwin et al. 1999; Grotkopp et al. 2002; Richardson and Rejmánek 2004). However, in a review of the characteristics of plant invaders, Roy (1990) could find no physiological or genetic attributes common to all invaders. Roy (1990) emphasized that the interaction of ecological and evolutionary features of both the introduced species and the habitats they might invade was an important determinant of invasion success.

Certain characteristics of plant communities may predispose them to invasion. Resource availability can influence plant invasions and may be an inherent quality of a habitat or may be altered by disturbance (Orians 1984). Establishment of introduced species has been shown to increase with greater soil nutrients in both experimental studies (Hobbs 1989; Huenneke et al. 1990; Burke and Grime 1996; Knops et al. 1999; Dukes 2001; Fargione et al. 2003; Gross et al. 2005; but see Tilman 1997) and field observations (Planty-Tabacchi et al. 1996; Stohlgren et al. 1998, 1999, 2002; Bashkin et al. 2003). Exotic species have also been reported to increase with greater water (Rejmánek 1989; Davis and Pelsor 2001; Larson et al. 2001) and light (Knops et al. 1999; Maurer and Zedler 2002; Naeem et al. 2000) availability.

It has been proposed repeatedly that decreased species diversity in plant communities can encourage the establishment of invasive species (Elton 1958; Tilman 1997, 1999). Although many studies at the local scale support the contention that greater species richness (Knops et al. 1999; Naeem et al. 2000; Prieur-Richard et al. 2000; Kennedy et al. 2002) and functional diversity (Symstad 2000; Dukes 2001) provide resistance to invasion in plant communities, it has generally not been supported by large scale, observational studies (Smith and Knapp 1999; Lonsdale 1999; Stohlgren et al. 1999, 2002, 2003; Bashkin et al. 2003). These contradictory relationships suggest that processes affecting invasions at the small, local scale are not the same as those responsible for large, landscape scale patterns of invasion (Levine 2000; Stohlgren et al. 2003).
More recently, researchers have followed the lead of Roy (1990) and have investigated the interactions between exotic species and the communities they invade. Several studies have tested the effects of resident species on invaders to evaluate invasibility of the community (Knops et al. 1999; Levine 2000; Naeem et al. 2000; Prieur-Richard et al. 2000; Symstad 2000; Lyons and Schwartz 2001; Dukes 2001, 2002; Kennedy et al. 2002; Brown 2004; Pokorny et al. 2005). A growing number have examined the impact that invaders have on communities (e.g., Dukes 2001, 2002) or ecosystem functioning (e.g., Vitousek 1987, 1990; Gordon 1998; Ehrenfeld et al. 2001). A few studies have explored whether introduced species from the same functional groups as resident species are less successful than when resident species are from different functional groups than the invader (Dukes 2001, 2002; Fargione et al. 2003; Bakker and Wilson 2004; Pokorny et al. 2005).

The aim of our study was to compare the susceptibility to invasion of communities composed of species that have large overlap in resource use with communities of species that have limited overlap. In addition we investigated effects on invasion of interactions between patterns of resource use and species richness. We expected plant communities that included species with different resource use patterns (e.g., earlyvs. late-season phenology or shallow vs. deep rooting) would more completely utilize resources in space and time, and thus reduce the success of invaders. We also expected that species rich communities would reduce invader success because a diversity of species with differing patterns of resource use should minimize the availability of residual resources for invaders.

To test these hypotheses, we studied how soil fertility and patterns of belowground resource use and biomass production in different communities affected the establishment, growth and reproduction of two invasive grassland species that differ in growth form and phenology. We used an early-season, shallow rooting (Brown 1998; Gordon and Rice 1992) annual grass, Bromus hordeaceus (soft chess), and a late-season, deep rooting (Brown 1998; Enloe et al. 2005) annual forb, Centaurea solstitialis (yellow starthistle). These species were selected as invaders because of their contrasting spatial and temporal resources use patterns. In contrast to previous studies on effects of functional group similarity on invasion, we examined grassland communities that evolved in a Mediterranean climate and 
conducted the experiment in field plots, which allowed roots to grow freely. In addition, the experiment was conducted at two sites that were established 2 years prior to invader introduction.

\section{Materials and methods}

\section{Site descriptions}

The study was conducted at two field sites in Yolo County in the Sacramento Valley of California, USA: (1) Hedgerow Farms located at the west side of the Valley (lat $38^{\circ} 36^{\prime} \mathrm{N}$, long $121^{\circ} 59^{\prime} \mathrm{W}$ ) (hereafter the less fertile site), and (2) the Student Experimental Farm located at the University of California-Davis campus (lat $38^{\circ} 32^{\prime} \mathrm{N}$, long $121^{\circ} 46^{\prime} \mathrm{W}$ ) (hereafter the more fertile site). The soils at the Student Farm site are Reiff fine sandy loam and Yolo silt loam (Huntington et al. 1981), and are classified as mixed, nonacid, thermic Typic Xerothents (Andrews 1990). These are welldrained, alluvial soils with moderately high to high fertility (Table 1) (Andrews 1990). The soils at the Hedgerow Farms site are predominantly Corning red gravely loam, a fine, montmorillonitic, thermic Typic Palexeralf that is found on terraces within the Central Valley. This soil type is relatively well-drained and is of moderate fertility (Table 1) (Andrews 1990).

\section{Precipitation patterns 1996-1998}

The climate at the study sites is typically Mediterranean; rain falls during the cool winter months and there is little or no precipitation in the summer when warm temperatures are most conducive to plant growth. Precipitation data were from a weather station managed by the University of California, Department of Land, Air and Water Resources, located at the U.C. Davis experimental farm, within $1.6 \mathrm{~km}$ of the more fertile site, and within 24 aerial $\mathrm{km}$ of the less fertile site. Although the average annual precipitation in Davis for 1996-1997 was $467 \mathrm{~mm}$, close to the 30 years average of $460 \mathrm{~mm}$ (Owenby and Ezell 1992), the pattern of rainfall was unusual. Precipitation in January was $220 \%$ (220 mm) of the 30 years average. Precipitation in February, March and April was a fraction of normal with $0.9,16$ and $11 \%$ of the 30 years average falling, respectively. Because May and June rainfall was about $30 \%$ higher than the

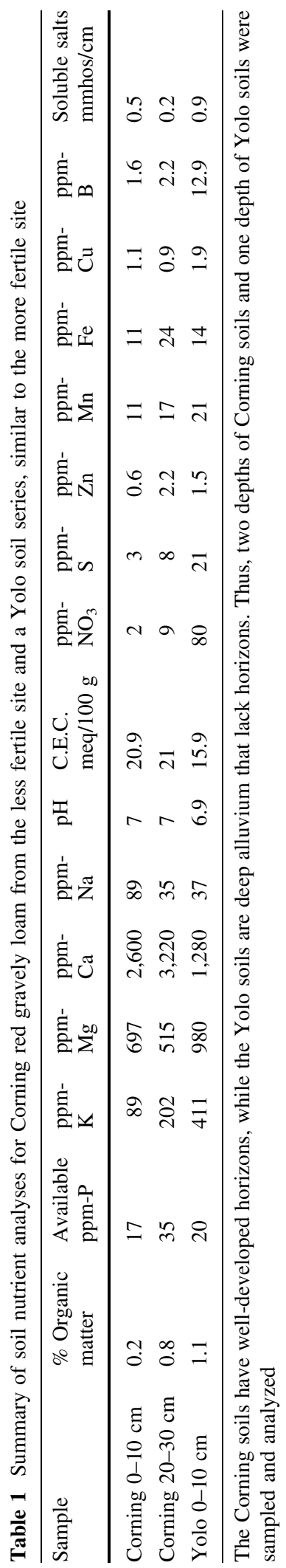


30 years average, soil water availability was higher in the early summer than in most years.

The wet season for 1997-1998 began in the fall of 1997 with $111 \mathrm{~mm}$ of rain falling in November, or about $150 \%$ of the 30-years average. Rainfall for December 1997 and January 1998 were close to the average, but precipitation was well above average for February ( $298 \mathrm{~mm}$, or $410 \%$ of the 30 years average) and May (59 mm, or $835 \%$ of the 30 years average). Precipitation was below average for March $(47 \mathrm{~mm}$, or $70 \%$ of the 30 years average). The total rainfall accumulation of $565 \mathrm{~mm}$ during 1998 was $123 \%$ of the 30 years average, and, similar to 1996-1997, soil water availability was greater than normal in late spring/ early summer because of rainfall late in the season.

\section{Experimental design}

Constructed prairie communities were created within a $2 \times 2 \times 2$ factorial, randomized complete block design with the following factors: seeding density, functional diversity and species richness. The treatment combinations were replicated twice at each of the two field sites for a total of four blocks. Two densities of four plant community treatments were randomly assigned to treatment plots within blocks for a total of 32 experimental units. To realistically simulate community resource use patterns, treatment plots were large $(3 \mathrm{~m}$ by $4.5 \mathrm{~m})$. Before plots were planted, sites were disked and harrowed.

The constructed prairie communities were designed to be either functionally diverse or functionally simple based on the degree of overlap in spatial and temporal water use patterns of their constituent species. Using results from previous container and field studies on species monocultures (Brown 1998), we defined resource use characteristics for each species in terms of root length distribution with depth, phenology of growth and flowering, and average height. The resource use patterns of individual species and the species composition of experimental communities are listed in Table 2. The functionally diverse

Table 2 Growth, phenology, origin and life history characteristics of species for community experiment

\begin{tabular}{|c|c|c|c|c|c|c|c|}
\hline Community & Species & $\begin{array}{l}\text { Flowering } \\
\text { time }\end{array}$ & $\begin{array}{l}\text { Rooting } \\
\text { depth }\end{array}$ & Height & N-fixing & Origin & $\begin{array}{l}\text { Life } \\
\text { history }\end{array}$ \\
\hline \multirow[t]{2}{*}{$\begin{array}{l}\text { Two-species } \\
\text { Functionally diverse }\end{array}$} & $\begin{array}{l}\text { Hordeum brachyantherum } \\
\text { ssp. brachyantherum }\end{array}$ & Early & Deep & Intermediate & No & Native & Perennial \\
\hline & Poa secunda $\mathrm{ssp}$ secunda ${ }^{\mathrm{b}}$ & Early & Shallow & Short & No & Native & Perennial \\
\hline Two-species & Poa secunda ssp secunda & Early & Shallow & Short & No & Native & Perennial \\
\hline Functionally simple & Vulpia microstachys & Early & Shallow & Short & No & Native & Annual \\
\hline Five-species & Eremocarpus setigerus & Very late & Intermediate & Short & No & Native & Annual \\
\hline \multirow[t]{4}{*}{ Functionally diverse } & $\begin{array}{l}\text { Hordeum brachyantherum } \\
\text { ssp. brachyantherum }\end{array}$ & Early & Deep & Intermediate & No & Native & Perennial \\
\hline & Lotus purshianus & Late & Deep & Prostrate & Yes & Native & Annual \\
\hline & Nassella pulchra & Mid-late & Deep & Intermediate- tall & No & Native & Perennial \\
\hline & Poa secunda ssp secunda & Early & Shallow & Short & No & Native & Perennial \\
\hline Five-species & Elymus multisetus & Mid-late & Intermediate & Short-intermediate & No & Native & Perennial \\
\hline \multirow[t]{4}{*}{ Functionally simple } & $\begin{array}{l}\text { Hordeum brachyantherum } \\
\text { ssp. brachyantherum }\end{array}$ & Early & Deep & Intermediate & No & Native & Perennial \\
\hline & Poa secunda ssp secunda & Early & Shallow & Short & No & Native & Perennial \\
\hline & Vulpia microstachys & Early & Shallow & Short & No & Native & Annual \\
\hline & Vulpia myuros & Early & Shallow & Short & No & Exotic & Annual \\
\hline \multirow[t]{2}{*}{ Invaders } & Bromus hordeaceus & Early & Shallow & Short-intermediate & No & Exotic & Annual \\
\hline & Centaurea solstitialis & Late & Deep & Tall & No & Exotic & Annual \\
\hline
\end{tabular}

Nomenclature is according to Hickman (1993)

a Nevski

b J.S. Pres 
communities were comprised of species with differing resource use patterns (i.e., reduced overlap in resource use), while the functionally simple communities contained species with more similar resource use patterns (i.e., higher overlap in resource use). Most species were included in both functional diversity treatments. However, Lotus purshianus (Benth.) Clements \& E.G. Clements and Eremocarpus setigerus (Hook.) Benth. occurred only in functionally diverse communities while Vulpia microstachys (Nutt.) Benth., Vulpia myuros (L.) C. Gmelin and Elymus multisetus (J.G. Smith) Burtt Davy occurred only in functionally simple communities.

Communities were also constructed with different numbers of species to examine the interactive effects of species richness and functional diversity on invasion resistance. Plant community treatments included two two-species communities (one functionally diverse and one functionally simple) and two fivespecies communities (one functionally diverse and one functionally simple). We were unable to include each species within all functional diversity and species richness treatment levels because of the need to maintain selected combinations of resource use patterns within functional diversity treatments (Brown 1998). Thus, E. setigerus, E. multisetus, L. purshianus, Nassella pulchra, and V. myuros occurred only in fivespecies communities.

More diverse plant communities are more likely to include species whose resource requirements overlap with invasive species and thus, will compete more directly with invading species for essential resources. This is a result of the 'selection probability effect' (Huston 1997) or 'sampling effect,' which is a factor in experiments in which diversity treatments are determined by random selection from a pool of species, and the tendency for a community to reflect the characteristics of species with the most dominant traits (Huston 1997; Aarssen 1997). We avoided the probabilistic 'sampling effect' by selecting species based on their resource use patterns. However, like natural plant communities, the characteristics of our experimental communities reflected the traits of the species they comprise. If one or more resident species was highly dominant (the 'selection effect' sensu Loreau and Hector 2001), or if the species partitioned resources resulting in greater total resource use (the 'complementarity effect' sensu Loreau and Hector 2001), these characteristics would be expressed by the plant community. We did not distinguish between 'selection' and 'complementarity' effects in our study.

Each community was planted at high (1,076 live seeds $/ \mathrm{m}^{2}$ ) and low (269 live seeds $/ \mathrm{m}^{2}$ ) densities that spanned the range typically used for revegetation projects in California. Communities were formulated with equal numbers of viable seeds of each species. We planted the seeds by evenly sprinkling preweighed seeds mixed with wheat bran (to facilitate even distribution of seeds) over each plot. We then hand raked the soil to incorporate the seed. The less fertile site was planted on 22 November 1994; planting at the more fertile site was delayed until 24 February 1995 due to soil conditions and logistical constraints.

The more fertile site was irrigated during the plant community emergence and establishment periods because of its relatively late planting. Approximately $0.7 \mathrm{~cm}$ of water on 1 March and 24 April, and $1.4 \mathrm{~cm}$ of water on 25 May was applied with impact sprinklers. The last natural rainfall of 1994-1995 at all sites was on 15 June.

Seeds of most species were purchased from commercial seed suppliers (Pacific Coast Seed, Livermore, California, USA; Hedgerow Farms, Winters, California, USA; Conservaseed, Rio Vista, California, USA). Seeds of E. setigerus were collected from wild plants near Davis, California during the summer of 1994. Seed germination tests of E. setigerus were conducted using the methods of the Association of Official Seed Analysts (Wiesner 1989). Germination rates of commercial sources of seed were determined by commercial seed laboratories. Germination rates were used to calculate seeding rates. Lotus purshianus seeds were inoculated with appropriate rhizobia culture (The Nitragin Company, Liphatec, Inc. Milwaukee, Wisconsin, USA).

Species that were not intentionally planted (i.e., weeds) were removed and prevented from establishing. At the less fertile site, treatment plots that contained only grasses were sprayed with broadleaf specific herbicides as follows: triclopyr-18 March 1995 (0.56 kg ha $\left.{ }^{-1}\right)$ and again 28 March 1995 (0.84 $\mathrm{kg} \mathrm{ha}^{-1}$ ) because rain fell within $4 \mathrm{~h}$ of the first application; dicamba-8 to 12 May $1995\left(1.4 \mathrm{~kg} \mathrm{ha}^{-1}\right)$ and 15 March 1996 (1.87 kg ha $\left.{ }^{-1}\right)$. Furrows between beds at the less fertile site were cultivated with a tractor drawn implement on 6 April 1995 to control weeds. Hand weeding was conducted at both sites in all plots from 1995 through 1998. 
Invader introduction

In the fall of 1996, the beginning of the third growing season of the constructed plant communities, the invaders Bromus hordeaceus (hereafter Bromus) and Centaurea solstitialis (hereafter Centaurea) were planted into the constructed communities. In the fall of 1997, the experiment was repeated with Centaurea alone.

The $3 \mathrm{~m}$ by $4.5 \mathrm{~m}$ plots were divided into six subplots that were $1.5 \mathrm{~m}$ on a side. Invader species treatments were randomly assigned to subplots within each plot (one subplot each of Bromus or Centaurea at high and low density for four subplots per plot; no invader treatment was assigned to two subplots). Each invader species was planted at two densities. The high density treatment was 36 seeds planted equidistant from each other in a $0.063 \mathrm{~m}^{2}$ grid $(25 \mathrm{~cm}$ by $25 \mathrm{~cm}$, with $5 \mathrm{~cm}$ between seeds). The low density treatment was 36 seeds planted equidistant from each other in a $1.0 \mathrm{~m}^{2}$ grid $(1 \mathrm{~m}$ by $1 \mathrm{~m}$, with $20 \mathrm{~cm}$ between seeds). Seeds were planted at a depth of $0.5-1.0 \mathrm{~cm}$. For the first year of the experiment, replicates at the more fertile site were planted from 28 to 31 October 1996 and those at the less fertile site were planted on 2-3 November 1996. For the second year, the more fertile site was planted on 16-17 September 1997 and the less fertile site was planted on 11 and 15 September 1997. No Centaurea seedlings survived in the first year of the experiment. Thus in the second year, the seeding rate was increased to 108 seeds of Centaurea planted at the two densities with three seeds at each grid point and seeds were placed less than $0.5 \mathrm{~cm}$ deep. The communities at the more fertile site were watered with furrow and sprinkler irrigation 23 October to 5 November 1997. This was unintentionally initiated by an accidental breach of an irrigation ditch at the more fertile site. The less fertile site was not irrigated at this time. Centaurea emergence was noted on 3 November and the first natural rainfall after planting was on 20 November 1997. Centaurea emergence and initial growth of the resident plant communities occurred earlier at the more fertile site due to the irrigation, which may have heightened differences between sites. However, these effects were likely small because natural precipitation began 2 weeks later and was $50 \%$ higher than the 30 -years average for the month, which initiated growth at the less fertile site that was not irrigated.
Centaurea seeds planted in fall of both 1996 and 1997 were collected from wild populations near Davis, California in August of 1996. Bromus seeds were obtained from Albright Seed Company (Camarillo, California) in 1989. Germination rates of seeds were tested using modified methods described in the Official Seed Testing Handbook (Wiesner 1989). Centaurea germination was $72.5 \pm 3.35 \%$ (mean \pm standard error of the mean) and Bromus germination was $86.0 \pm 3.0 \%$ (both are the mean percentage of 300 seeds \pm standard error of the mean).

Measurement of constructed plant communities

We measured density and obtained non-destructive estimates of biomass from the two subplots within each plot not seeded with invaders. We estimated density by placing a $0.1 \mathrm{~m}^{2}$ quadrat in the center of each subplot and counting the number of individuals of each species rooted in the quadrat. Individuals of each seeded species that were closest to two random, fixed points on the quadrat were measured for nondestructive biomass estimates. The traits that could be non-destructively measured and were most strongly correlated with total biomass, such as plant height, length of longest leaf or basal diameter, were determined for each seeded species by measuring and harvesting plants growing adjacent to the experimental plots. The harvested plants were dried and weighed and best-fit multiple regressions were generated for each species at each phenological stage (BMDP New System for Windows version 1.0, BMDP Statistical Software, Ind., Los Angeles, California, USA). The non-destructive measurements from the two individuals of each species in each quadrat were entered into the appropriate multiple regression equation to generate estimates of biomass per plant for each subplot. Subplot biomass estimates for each species were the product of estimates of subplot density and biomass per plant for each species and phenological stage.

Estimates of species composition and biomass were taken during periods of peak standing biomass. We completed sampling of each block within 1 week. Density and biomass measurements were taken for all species of the constructed communities 8-16 April 1997 and 19 June to 9 July 1998. Despite the difference in sampling date between years, data were comparable because non-destructive measures did not 
change once peak standing biomass was reached. We re-sampled plots on 20 August 1998 to obtain estimates of density and peak biomass of L. purshianus and E. setigerus, the only species that actively grew during the summer. Due to difficulty in distinguishing between $V$. myuros and V. microstachys under some conditions, biomass estimates for these two species were combined when necessary (i.e., Vulpia spp.).

\section{Measurement of Bromus hordeaceus}

We did not evaluate initial emergence of Bromus because it was impossible to distinguish its seedlings from those of other weedy annual grasses. Bromus plants surviving to flowering were censused and harvests for biomass and reproductive potential (see below) were made from 23 to 25 April 1997. We counted the number of Bromus plants within the area where seed was originally planted. We then harvested the three individual plants closest to the center of the subplot. The vegetative parts of the plants were dried at $100^{\circ} \mathrm{C}$ for an hour to arrest carbon loss through respiration and then at $60-65^{\circ} \mathrm{C}$ to constant weight (24 h).

Using total number of spikelets and the average number of florets per spikelet (determined by counting the florets in a subsample of spikelets on each plant), we were able to estimate the number of florets produced by each plant (i.e., its reproductive potential). In a sample of 30 plants, the mean number of florets per spikelet estimated with our subsampling method $(6.40 \pm 0.40)$ was not different from the actual mean number of florets per spikelet $(6.39 \pm 0.40)\left(t_{29}=\right.$ $-0.28, P=0.78)$. After counting, both inflorescences and vegetative parts were dried at $60-65^{\circ} \mathrm{C}$ to constant weight (24 h).

\section{Measurement of Centaurea solstitialis}

In 1998, when only Centaurea was planted, initial emergence was determined by counting the number of seedlings in each subplot on 27-28 February. For peak biomass and density estimates, we counted the number of Centaurea plants within the subplots and selected for measurement two plants closest to the center of the subplot and two plants closest to two randomly selected diagonal corners of the subplot. The flower heads (mature and immature) on each plant were counted and the diameters of 30 flower heads that were in full bloom were measured. Centaurea density measurements and harvests were conducted 16-31 July 1998 at the more fertile site and 3-7 August 1998 at less fertile site. Biomass samples were dried at $55^{\circ} \mathrm{C}$ to constant weight (24 h) and weighed.

There was a highly significant positive relationship between fresh flower head diameter and ovule number (ovules/flower head $=11.56+5.58$ (flower head wet diameter), $P<0.0001, R^{2}=0.62$ ) based on mean flower head diameter and ovule numbers of 27 plants harvested from control plots (only Centaurea neighbors) in 1996-1997. This relationship was used to estimate the reproductive potential (i.e., the number of ovules produced) of individual plants harvested in 1998.

\section{Statistical analysis}

Plant community biomass data were analyzed using a mixed model analysis of variance (ANOVA) with site, functional diversity treatment, and species richness treatment as fixed effects and block as a random effect nested within site (SAS 9.1, SAS Institute, Cary, North Carolina, USA).

The experimental design for invader performance was a split-plot design with functional diversity and species richness treatments as main-plot factors and invader density as a split-plot factor. The two invader species were evaluated separately. Data were analyzed using a mixed model ANOVA with site, functional diversity treatment, and species richness treatment as fixed effects and block as a random effect nested within site (SAS 9.1, SAS Institute, Cary, North Carolina, USA). The Kenward-Roger method was used for calculation of degrees of freedom.

Proportional data were arcsine-square root transformed, and biomass and reproductive potential data were $\log _{10}$ transformed to improve their distributional properties. Results for individual plants (average of plants within a subplot) and populations (sum of plants within a subplot) were similar for each invader, thus, only the results for populations are presented for simplicity. Tukey's studentized range test was used for post hoc mean separation when more than two means were being compared and the ANOVA was significant. Statistical significance was set at $P<0.05$, unless otherwise stated. 
Initially, we included seeding density of the community as a fixed effect in the statistical models described above. However, no main effects of community seeding density were significant. In analyses of community and invader responses, the only interactions with seeding density that were significant were two three-way and one four-way interaction for Centaurea emergence and one fourway and one five-way interaction for Centaurea reproductive potential. Furthermore, results of analyses with and without seeding density were qualitatively similar. Thus, seeding density was eliminated from subsequent analyses.

Simple linear regression was used to examine relationships among community aboveground biomass, light penetration to the soil surface, and invader performance measures (JMP 7.0.7, SAS Institute, Cary, North Carolina, USA).

\section{Results}

Constructed plant communities

In 1996-1997, effects of functional diversity treatments on total aboveground biomass production depended on site and species richness treatment (Fig. 1a, b; Table 3). Functionally diverse communities at the less fertile site $\left(284.05 \pm 82.73 \mathrm{~g} \mathrm{~m}^{-2}\right)$ produced less biomass than functionally simple communities at that site $(858.46 \pm$ $\left.113.39 \mathrm{~g} \mathrm{~m}^{-2}\right)(P<0.0001$; Fig. 1a; Table 3$)$, but we detected no difference between functionally diverse $\left(727.54 \pm 365.98 \mathrm{~g} \mathrm{~m}^{-2}\right)$ and functionally simple $\left(636.96 \pm 152.10 \mathrm{~g} \mathrm{~m}^{-2}\right)$ communities at the more fertile site $(P=0.86$; Fig. $1 b$; Table 3$)$. Two-species functionally diverse communities (177.79 \pm 45.38 $\mathrm{g} \mathrm{m}^{-2}$ ) produced less biomass than five-species functionally diverse communities $\left(833.80 \pm 349.33 \mathrm{~g} \mathrm{~m}^{-2}\right.$ ) $(P<0.0001)$, but the difference between two- and fivespecies functionally simple communities was not as great $\left(522.16 \pm 98.88\right.$ and $973.25 \pm 123.23 \mathrm{~g} \mathrm{~m}^{-2}$, respectively) $(P=0.06)$. Overall, functionally diverse communities $(505.80 \pm 190.07)$ produced less biomass than functionally simple communities (747.71 \pm 96.00 $\left.\mathrm{g} \mathrm{m}^{-2}\right)(P<0.0001)$ and two-species communities $\left(349.98 \pm 68.83 \mathrm{~g} \mathrm{~m}^{-2}\right)$ produced less biomass than five-species communities $\left(903.53 \pm 179.84 \mathrm{~g} \mathrm{~m}^{-2}\right)$ $(P<0.0001)$.
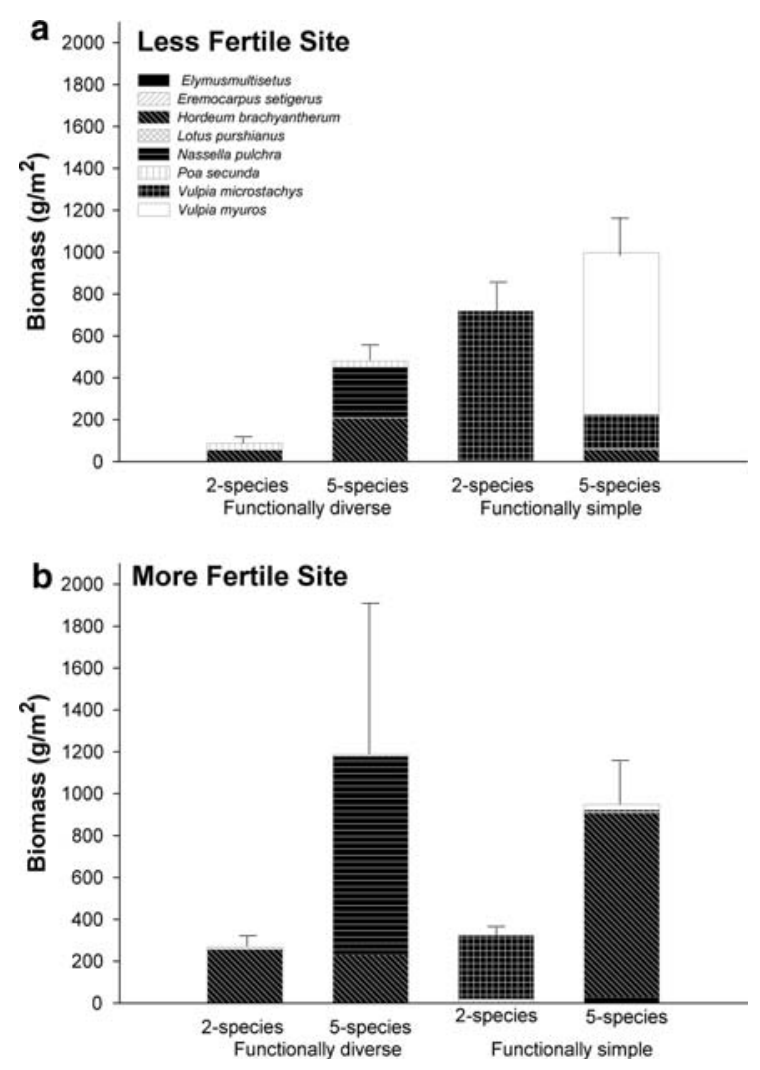

Fig. 1 Biomass production of functionally diverse, functionally simple, two-species, and five-species constructed communities without invaders in 1996-1997 at the less fertile site (a) and more fertile site (b)

In 1997-1998, effects of functional diversity on total aboveground biomass depended on site and species richness treatment (Fig. 2a, b; Table 3). This was primarily due to differences between two- and five-species functionally simple communities at the more fertile site $(913.73 \pm 279.24$ and $3,907.77 \pm$ $676.10 \mathrm{~g} \mathrm{~m}^{-2}$, respectively) $(P=0.01)$ that were not detected at the less fertile site $(740.31 \pm 318.81$ and $1,399.84 \pm 290.22 \mathrm{~g} \mathrm{~m}^{-2}$ for two- and five-species, respectively) $(P=0.55)$, and differences between two-species functionally diverse and two-species functionally simple communities $(3,172.35 \pm 762.91$ and $913.73 \pm 279.24 \mathrm{~g} \mathrm{~m}^{-2}$, respectively) at the more fertile site $(P=0.04)$ that were not detected at the less fertile site $(584.33 \pm 178.01$ and $740.31 \pm 318.81$ $\mathrm{g} \mathrm{m}^{-2}$ for two-species functionally diverse and twospecies functionally simple, respectively) $(P=1.00)$. Averaging across sites, effects of functional diversity depended on species richness treatment (Table 3). Two- 
Table 3 Mixed model analysis of variance results for analysis of community biomass in 1996-1997 and 1997-1998

\begin{tabular}{|c|c|c|c|c|c|}
\hline \multirow[t]{2}{*}{ Source of variation } & \multirow[t]{2}{*}{$d f$} & \multicolumn{2}{|c|}{ 1996-1997 } & \multicolumn{2}{|c|}{ 1997-1998 } \\
\hline & & $F$ & $P$ & $F$ & $P$ \\
\hline Site & 1,2 & 0.59 & 0.52 & 12.78 & 0.07 \\
\hline Functional diversity & 1,22 & 22.64 & $<0.0001$ & 0.01 & 0.93 \\
\hline Site $\times$ functional diversity & 1,22 & 13.23 & 0.001 & 1.34 & 0.26 \\
\hline Species richness & 1,22 & 38.13 & $<0.0001$ & 8.47 & 0.008 \\
\hline Site $\times$ species richness & 1,22 & 0.00 & 0.98 & 0.32 & 0.57 \\
\hline Functional diversity $\times$ species richness & 1,22 & 5.43 & 0.03 & 9.22 & 0.006 \\
\hline Site $\times$ functional diversity $\times$ Species richness & 1,22 & 4.08 & 0.06 & 7.12 & 0.01 \\
\hline
\end{tabular}

$P$ values $<0.05$ are indicated in bold
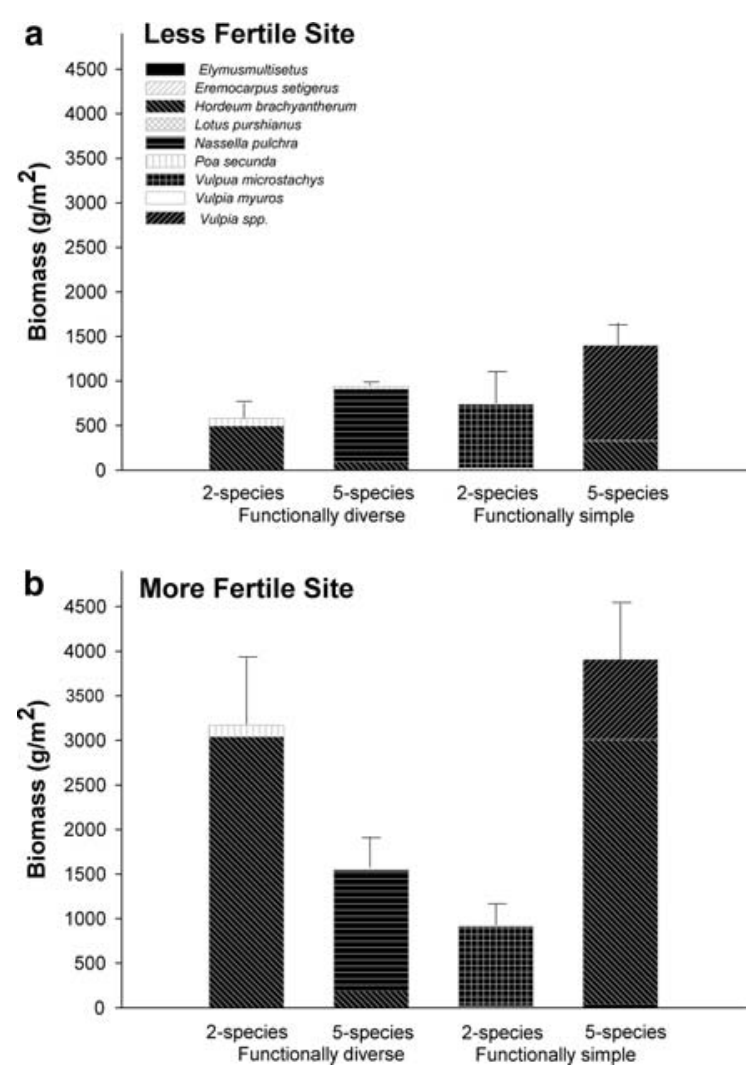

Fig. 2 Biomass production of functionally diverse, functionally simple, two-species, and five-species constructed communities without invaders in 1997-1998 at the less fertile site (a) and more fertile site (b)

species functionally simple communities (827.02 \pm $198.91 \mathrm{~g} \mathrm{~m}^{-2}$ ) produced less biomass than five-species functionally simple communities $(2,653.80 \pm 583.64$ $\left.\mathrm{g} \mathrm{m}^{-2}\right)(P=0.002)$, but there were no differences among any other treatment pairs (two-species functionally diverse: $1,878.34 \pm 608.87 \mathrm{~g} \mathrm{~m}^{-2}$; five-species functionally diverse: $1,247.66 \pm 201.08 \mathrm{~g} \mathrm{~m}^{-2}$ ) $(P>0.1)$. Overall, two-species communities $(1,352.68 \pm$ $337.87 \mathrm{~g} \mathrm{~m}^{-2}$ ) produced less aboveground biomass than five-species communities $(1,950.73 \pm 349.10$ $\mathrm{g} \mathrm{m}^{-2}$ ) (Table 3).

\section{Bromus hordeaceus performance}

Survival of Bromus in 1996-1997 (the only year it was planted) was greater in functionally diverse communities $(22.22 \pm 3.92 \%)$ than functionally simple ones $(6.51 \pm 1.41)$, but this depended on site (Fig. 3a, b; Table 4). Survival at the less fertile site was greater in functionally diverse communities $(39.58 \pm 4.48 \%)$ than functionally simple communities $(6.94 \pm 2.40 \%)$ $(P=0.001)$, but survival did not differ between functionally diverse and simple communities at the more fertile site $(4.86 \pm 1.87$ and $6.08 \pm 1.55 \%$, respectively) $(P=0.84)$. Regardless of site, a higher percentage of individuals from seeds planted into twospecies communities $(17.27 \pm 3.43 \%)$ survived to flowering than those in five-species communities $(11.46 \pm 3.00 \%)$.

Effects of functional diversity and species richness on Bromus biomass depended on site (Fig. 3c, d; Table 4). At the less fertile site, Bromus biomass was greater in functionally diverse communities (4.50 \pm $\left.1.86 \mathrm{~g} \mathrm{~m}^{-2}\right)$ than functionally simple ones $(0.60 \pm$ $\left.0.26 \mathrm{~g} \mathrm{~m}^{-2}\right)(P=0.02)$, but there was no difference between functionally diverse and simple treatments at the more fertile site $\left(0.15 \pm 0.09,0.10 \pm 0.03 \mathrm{~g} \mathrm{~m}^{-2}\right.$, respectively) $(P=1.00)$. Bromus biomass was greater 
Fig. 3 Bromus hordeaceus percent survival to flowering (a, b), biomass $(\mathbf{c}, \mathbf{d})$ reproductive potential $(\mathbf{e}, \mathbf{f})$ of plants from seeds introduced into functionally diverse (species with differing resource use patterns) and functionally similar communities (species with similar resource use patterns), and into two-species and fivespecies communities at the two study sites (36 seeds planted in each plot) in 1996-1997. Bars are the mean \pm standard error of the mean
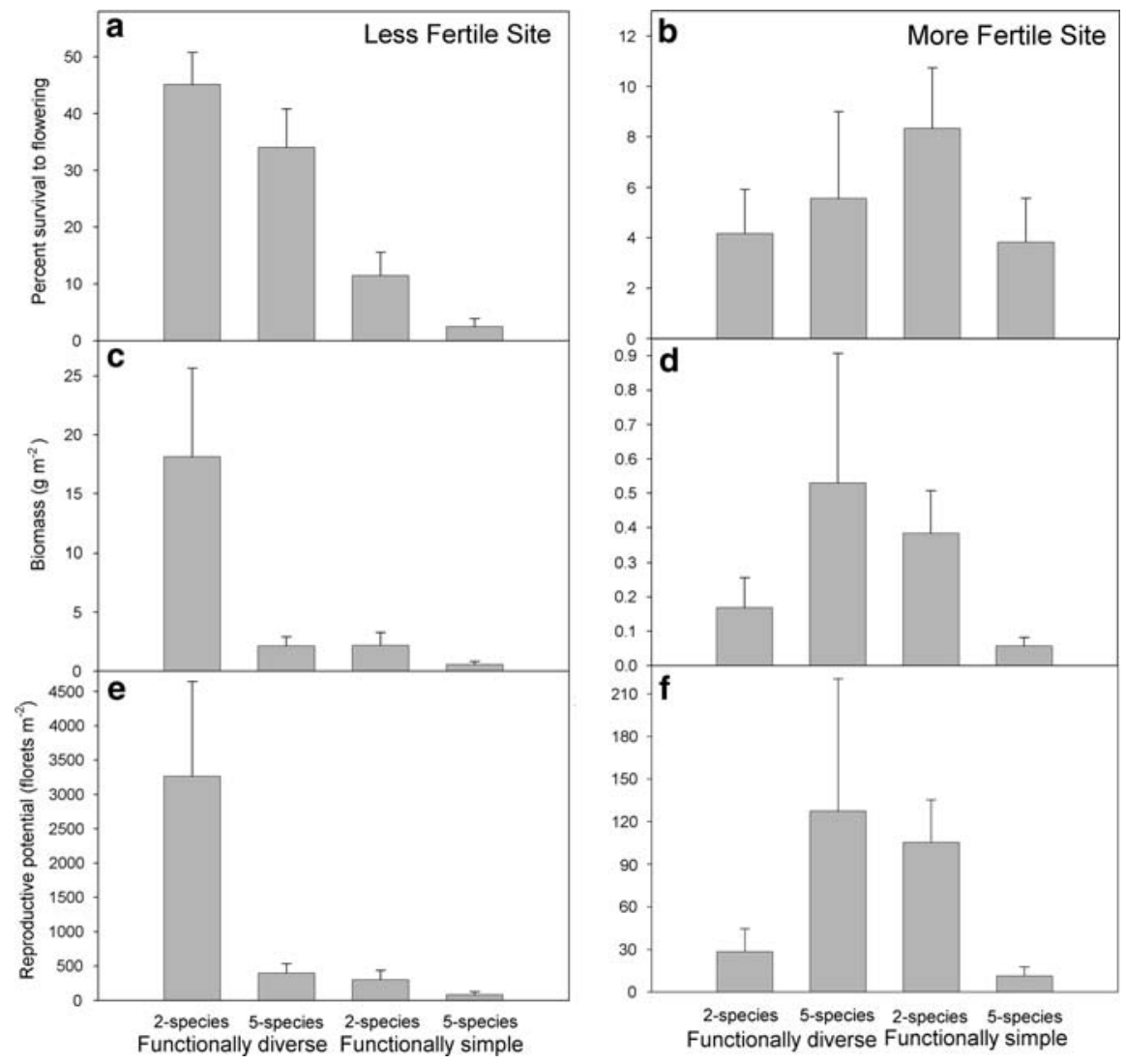

in two-species $\left(4.51 \pm 1.87 \mathrm{~g} \mathrm{~m}^{-2}\right)$ than five-species $\left(0.59 \pm 0.20 \mathrm{~g} \mathrm{~m}^{-2}\right)$ communities at the less fertile site $(P=0.03)$, but there was no difference in its response to species richness treatments at the more fertile site $\left(0.12 \pm 0.03\right.$ and $0.13 \pm 0.08 \mathrm{~g} \mathrm{~m}^{-2}$, respectively) $(P=1.00)$.

The effects of functional diversity on Bromus reproductive potential depended on site (Fig. 3e, f; Table 4). Bromus reproductive potential was greater in functionally diverse communities (1,647.52 \pm 689.19 florets $\left.\mathrm{m}^{-2}\right)$ than functionally simple ones $(171.30 \pm$ 67.57 florets $\left.\mathrm{m}^{-2}\right)$ at the less fertile site $(P<0.0001)$, but we detected no difference between these treatments at the more fertile site $(70.09 \pm 42.75,55.68 \pm 19.48$, respectively) $(P=0.87)$. Bromus reproductive potential was greater in two-species communities (858.81 \pm 368.00 florets $\mathrm{m}^{-2}$ ) than five-species communities $\left(119.47 \pm 39.25\right.$ florets $\left.\mathrm{m}^{-2}\right)$ regardless of site.

Bromus survival, biomass, and reproductive potential were strongly negatively associated with community biomass $\left(R^{2}=0.41, P<0.0001 ; R^{2}=0.49, P<0.0001\right.$; $R^{2}=0.32, P=0.0007$, respectively; $n=32$ ).

\section{Centaurea solstitialis performance}

In 1996-1997, when Centaurea was planted but did not survive, emergence was greater at the less fertile site $(11.82 \pm 2.04 \%)$ than the more fertile site $(0.65 \pm$ $0.29 \%)\left(F_{1,8.58}=59.71, P<0.0001\right)$. Emergence was also greater in two-species communities $(8.51 \pm$ $2.20 \%)$ than five-species communities $(3.93 \pm 0.95 \%)$ $\left(F_{1,8.58}=5.83, P=0.04\right)$.

Centaurea survival in 1997-1998 did not differ between sites, functional diversity treatments, or species richness treatments (Fig. 4a, b; Table 5). Centaurea biomass in species richness treatments depended on site and on functional diversity (Fig. 4c, d; Table 5). At the more fertile site, Centaurea biomass was much greater in two-species communities $\left(3,648.82 \pm 1155.60 \mathrm{~g} \mathrm{~m}^{-2}\right)$ than in five-species communities $\left(477.46 \pm 207.15 \mathrm{~g} \mathrm{~m}^{-2}\right)(P<0.0001)$, but we detected no difference in its biomass between two-species $\left(1,658.53 \pm 1,299.93 \mathrm{~g} \mathrm{~m}^{-2}\right)$ and five-species $\left(193.27 \pm 50.94 \mathrm{~g} \mathrm{~m}^{-2}\right)$ communities at the less fertile site $(P=0.83)$. Centaurea produced greater 
Table 4 Split-plot mixed model analysis of variance results for Bromus performance measures in 1996-1997

\begin{tabular}{|c|c|c|c|c|c|c|c|c|c|}
\hline \multirow[t]{2}{*}{ Source of variation } & \multicolumn{3}{|c|}{ Percent survival } & \multicolumn{3}{|c|}{ Aboveground biomass } & \multicolumn{3}{|c|}{ Reproductive potential } \\
\hline & $d f$ & $F$ & $P$ & $d f$ & $F$ & $P$ & $d f$ & $F$ & $P$ \\
\hline Site & 1,2 & 6.78 & 0.12 & 1,2 & 6.1 & 0.13 & $1,2.09$ & 7.75 & 0.10 \\
\hline Functional diversity & 1,6 & 24.01 & 0.003 & 1,6 & 10.81 & 0.02 & $1,43.1$ & 8.87 & 0.005 \\
\hline Site $\times$ functional diversity & 1,6 & 36.73 & 0.0009 & 1,6 & 9.46 & 0.02 & $1,43.1$ & 16.68 & 0.0002 \\
\hline Species richness & 1,6 & 6.78 & 0.04 & 1,6 & 8.33 & $\mathbf{0 . 0 3}$ & $1,43.1$ & 10.77 & 0.002 \\
\hline Site $\times$ species richness & 1,6 & 1.03 & 0.35 & 1,6 & 7.74 & $\mathbf{0 . 0 3}$ & $1,43.1$ & 0.16 & 0.69 \\
\hline Functional diversity $\times$ species richness & 1,6 & 1.33 & 0.29 & 1,6 & 1.78 & 0.23 & $1,43.1$ & 2.40 & 0.13 \\
\hline $\begin{array}{l}\text { Site } \times \text { functional diversity } \times \text { species } \\
\text { richness }\end{array}$ & 1,6 & 0.15 & 0.71 & 1,6 & 4.53 & 0.07 & $1,43.1$ & 2.65 & 0.11 \\
\hline Invader density & 1,40 & 2.65 & 0.11 & 1,40 & 0.13 & 0.72 & $1,43.4$ & 0.33 & 0.57 \\
\hline Site $\times$ invader density & 1,40 & 0.67 & 0.42 & 1,40 & 1.40 & 0.24 & $1,43.4$ & 1.29 & 0.26 \\
\hline Functional diversity $\times$ invader density & 1,40 & 0.76 & 0.39 & 1,40 & 0.34 & 0.56 & $1,43.4$ & 0.30 & 0.59 \\
\hline $\begin{array}{l}\text { Site } \times \text { functional diversity } \\
\times \text { invader density }\end{array}$ & 1,40 & 0.00 & 1.00 & 1,40 & 1.26 & 0.27 & $1,43.4$ & 0.58 & 0.45 \\
\hline Species richness $\times$ invader density & 1,40 & 0.35 & 0.56 & 1,40 & 0.29 & 0.59 & $1,43.4$ & 0.10 & 0.75 \\
\hline Site $\times$ species richness $\times$ invader density & 1,40 & 2.05 & 0.16 & 1,40 & 0.18 & 0.67 & $1,43.4$ & 1.47 & 0.23 \\
\hline $\begin{array}{l}\text { Functional diversity } \times \text { species richness } \\
\times \text { invader density }\end{array}$ & 1,40 & 1.02 & 0.32 & 1,40 & 1.64 & 0.21 & $1,43.4$ & 2.12 & 0.15 \\
\hline $\begin{array}{l}\text { Site } \times \text { functional diversity } \times \text { species } \\
\text { richness } \times \text { invader density }\end{array}$ & 1,40 & 0.26 & 0.61 & 1,40 & 0.04 & 0.85 & $1,43.4$ & 0.01 & 0.9 \\
\hline
\end{tabular}

Percent survival data were arcsine square root transformed and biomass and reproductive potential were $\log _{10}$ transformed for analysis. Degrees of freedom $(d f)$ are numerator and denominator degrees of freedom, respectively. Degrees of freedom were calculated using the Kenward-Roger method

$P$ values $<0.05$ are indicated in bold

biomass in two-species $\left(3,681.05 \pm 1,657.80 \mathrm{~g} \mathrm{~m}^{-2}\right)$ than five-species $\left(81.64 \pm 35.81 \mathrm{~g} \mathrm{~m}^{-2}\right)$ functionally diverse communities $(P<0.0001)$. However, there was no detectable difference between Centaurea biomass in two-species $\left(1,626.30 \pm 517.93 \mathrm{~g} \mathrm{~m}^{-2}\right)$ and five-species $\left(589.10 \pm 195.78 \mathrm{~g} \mathrm{~m}^{-2}\right)$ functionally simple communities $(P=0.10)$.

Centaurea reproductive potential in two-species communities was greater than five-species communities, but this depended on site (Fig. 4e, f; Table 5). As with biomass, Centaurea reproductive potential was greater in two-species communities $(287,288.83 \pm$ $49,575.39$ ovules $\mathrm{m}^{-2}$ ) than five-species communities $\left(84,485.78 \pm 36,091.43\right.$ ovules $\left.\mathrm{m}^{-2}\right)$ at the more fertile site $(P=0.005)$, but we detected no significant difference between two-species $(36,851.34 \pm$ $9,419.58$ ovules $\left.\mathrm{m}^{-2}\right)$ and five-species $(33,433.03 \pm$ 9,099.11 ovules $\mathrm{m}^{-2}$ ) communities at the less fertile site $(P=0.88)$.

Centaurea emergence in 1996-1997, and survival, biomass and reproductive potential in 1997-1998 were not significantly related to plant community aboveground biomass $\left(R^{2}=0.02, P=0.39 ; R^{2}=0.008\right.$, $P=0.62 ; R^{2}=0.05, P=0.19 ; R^{2}=0.05, P=0.21$; respectively; $n=32$ ).

\section{Discussion}

The composition of constructed prairie communities influenced the growth and reproduction of the invading species. Our results support the view that it is the interaction between characteristics of the invader and the existing plant community that determines invasion success. Performance of invader species appeared to depend upon the resource use patterns of the invader and of one or more of the species present in the constructed plant communities.

Resource use complementarity among resident species did not reliably reduce invader success. Invader responses to species richness and functional diversity treatments differed between sites. However, 
Fig. 4 Centaurea solstitialis percent survival to flowering $(\mathbf{a}, \mathbf{b})$, biomass $(\mathbf{c}, \mathbf{d})$ reproductive potential $(\mathbf{e}, \mathbf{f})$ of plants from seeds introduced into functionally diverse (species with differing resource use patterns) and functionally similar communities (species with similar resource use patterns), and into two-species and fivespecies communities at the two study sites (108 seeds planted in each plot) in 1997-1998. Bars are means \pm standard error of the mean
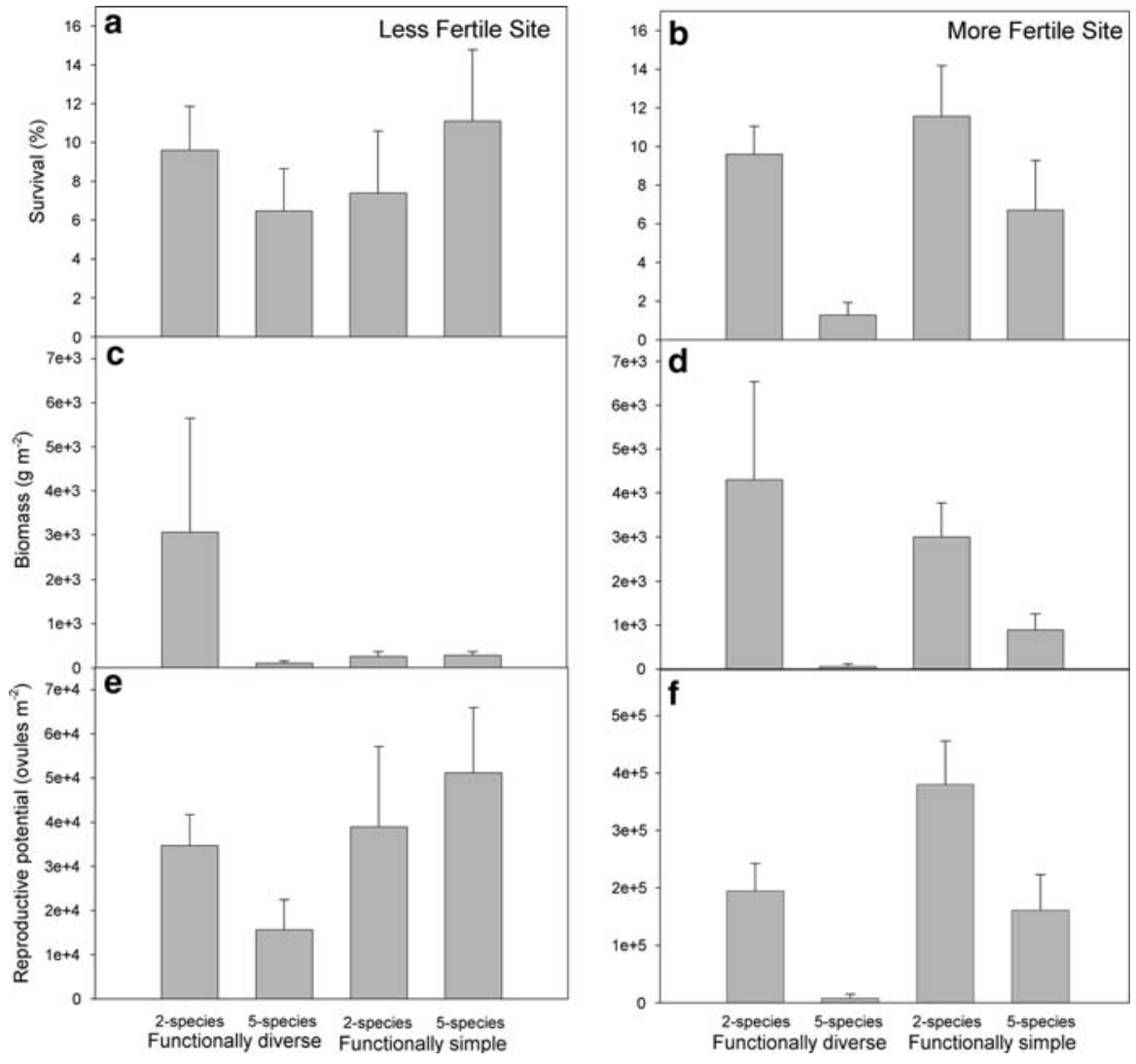

conclusions regarding invader responses to species richness or functional diversity must be tempered by the fact that there was only one combination of species for each community treatment (i.e., twospecies functionally diverse, two-species functionally similar, five-species functionally diverse, and fivespecies functionally similar). Thus, invader responses that suggested effects of species richness or functional diversity may have been due to the particular species or combination of species that we tested. Despite this, much can be learned from the patterns we observed.

We consistently observed that the biomass at the less fertile site was dominated by annual grasses, while the biomass at the more fertile site was dominated by perennial grasses. Bromus performance was inversely proportional to the biomass of the plant community at the less fertile site, which was dominated by earlyseason, shallow rooting annual species like Bromus (Figs. 1a, 3a, c, e; Table 4). At the more fertile site, Bromus performance measures were not inversely related to biomass of the community, but seemed to be influenced by biomass of particular species (Figs. 1b, $3 \mathrm{~b}, \mathrm{~d}, \mathrm{f}$ ). The measures of Bromus success were reduced when Hordeum brachyantherum, an early-season, deep rooting species, dominated the community biomass (five-species functionally simple community). Competition may have been especially keen between these two early-season species (Table 2) (Brown 1998) since rainfall was but a fraction of normal during February, March and April, prime time for growth of both species.

The measures of Bromus success were greater at the more fertile site when $N$. pulchra, a mid- to lateseason, deep rooting species dominated the plant community (five-species functionally diverse community) (Figs. 1b, 3b, d, f). The spatial and temporal resource requirements of Bromus may have been complementary to those of $N$. pulchra, effectively reducing competition between the two species (Table 2) (Brown 1998). This may have resulted in better performance of Bromus in the five-species functionally diverse community at the more fertile site even though the aboveground biomass production of this community was relatively high. The 
Table 5 Split-plot mixed model analysis of variance results for Centaurea performance measures in 1997-1998

\begin{tabular}{|c|c|c|c|c|c|c|c|c|c|}
\hline \multirow[t]{2}{*}{ Source of variation } & \multicolumn{3}{|c|}{ Percent survival } & \multicolumn{3}{|c|}{ Aboveground biomass } & \multicolumn{3}{|c|}{ Reproductive potential } \\
\hline & $d f$ & $F$ & $P$ & $d f$ & $F$ & $P$ & $d f$ & $F$ & $P$ \\
\hline Site & 1,2 & 0.48 & 0.56 & 1,2 & 0.44 & 0.58 & 1,2 & 0.02 & 0.90 \\
\hline Functional diversity & 1,6 & 0.54 & 0.49 & 1,46 & 1.20 & 0.28 & 1,6 & 0.91 & 0.38 \\
\hline Site $\times$ functional diversity & 1,6 & 0.68 & 0.44 & 1,46 & 2.16 & 0.15 & 1,6 & 3.10 & 0.13 \\
\hline Species richness & 1,6 & 3.15 & 0.13 & 1,46 & 25.18 & $<0.0001$ & 1,6 & 12.04 & 0.01 \\
\hline Site $\times$ species richness & 1,6 & 4.39 & 0.08 & 1,46 & 14.49 & 0.0004 & 1,6 & 20.38 & 0.004 \\
\hline Functional diversity $\times$ species richness & 1,6 & 2.00 & 0.21 & 1,46 & 7.17 & 0.01 & 1,6 & 4.98 & 0.07 \\
\hline Site $\times$ functional diversity $\times$ species richness & 1,6 & 0.10 & 0.76 & 1,46 & 0.12 & 0.73 & 1,6 & 0.10 & 0.76 \\
\hline Invader density & 1,40 & 0.00 & 0.99 & 1,46 & 0.29 & 0.59 & 1,40 & 1.75 & 0.19 \\
\hline Site $\times$ invader density & 1,40 & 0.89 & 0.35 & 1,46 & 0.07 & 0.79 & 1,40 & 0.26 & 0.61 \\
\hline Functional diversity $\times$ invader density & 1,40 & 0.00 & 0.96 & 1,46 & 0.70 & 0.41 & 1,40 & 0.01 & 0.93 \\
\hline Site $\times$ functional diversity $\times$ invader density & 1,40 & 2.06 & 0.16 & 1,46 & 2.32 & 0.13 & 1,40 & 0.93 & 0.34 \\
\hline Species richness $\times$ invader density & 1,40 & 0.69 & 0.41 & 1,46 & 2.54 & 0.12 & 1,40 & 0.90 & 0.35 \\
\hline Site $\times$ species richness $\times$ invader density & 1,40 & 0.00 & 0.98 & 1,46 & 0.00 & 0.95 & 1,40 & 0.24 & 0.63 \\
\hline $\begin{array}{l}\text { Functional diversity } \times \text { species richness } \\
\times \text { invader density }\end{array}$ & 1,40 & 0.05 & 0.83 & 1,46 & 0.09 & 0.76 & 1,40 & 0.13 & 0.72 \\
\hline $\begin{array}{l}\text { Site } \times \text { functional diversity } \times \text { species } \\
\text { richness } \times \text { invader density }\end{array}$ & 1,40 & 0.08 & 0.77 & 1,46 & 0.21 & 0.65 & 1,40 & 0.11 & 0.74 \\
\hline
\end{tabular}

Percent emergence and survival data were arcsine square root transformed and biomass and reproductive potential were $\log _{10}$ transformed for analysis. Degrees of freedom $(d f)$ are numerator and denominator degrees of freedom, respectively

$P$ values $<0.05$ are indicated in bold

measures of Bromus success were also greater when $V$. microstachys, an early-season, shallow rooting species, dominated the community biomass (twospecies functionally simple community) (Figs. 1b, $3 \mathrm{~b}, \mathrm{~d}, \mathrm{f})$. Since we expect the resource requirements of $V$. microstachys to be very similar to Bromus (Table 2) (Brown 1998), competition for belowground resources between these species was likely high in the two-species functionally simple community. Bromus may have flourished in this community because aboveground biomass production was relatively low, which may have released resources for Bromus to consume.

Centaurea performance measures tended to be lowest in the five-species functionally diverse community (Fig. 4). This was the only community that contained and was dominated by N. pulchra, a midto late-season deep rooting species (Fig. 2), similar to Centaurea (Table 2) (Brown 1998). Furthermore, this year had extraordinarily high precipitation late in the growing season, which extended moisture availability and the period of resource competition between Centaurea and other mid- to late-season species such as $N$. pulchra, which may have otherwise gone dormant (Table 2).

Since the aboveground biomass of the five-species functionally diverse community was not different from that of other communities (Fig. 2), our results suggest that competition for belowground resources may have been the primary cause of reductions in Centaurea survival, biomass and reproductive potential. In addition, we found no correlation between aboveground biomass of the plant community and Centaurea performance when composition treatments were not considered. Inclusion of community composition treatments, which correspond to belowground resource use patterns, in the statistical model was required to explain the variation in Centaurea performance measures. This supports that soil resources were relatively more important than light for success of Centaurea. This is not to say that other resources were not limiting for Centaurea. For example, Young (2007) found that Centaurea growth was limited by late-season perennial grasses, and he attributed this to competition for light early in the growing season, and competition for water late in the 
season. Similarly, DiTomaso et al. (2003) found that light limitation reduced Centaurea root growth.

Complementarity or overlap of resource use among species in a resident community appeared to affect invader success less than overlap of resource use between the invader and at least one of the species present in the resident community. Relatively poor performance of invaders in communities with resource use that overlaps its own has been widely reported (Dukes 2001; Fargione et al. 2003; Bakker and Wilson 2004; Pokorny et al. 2005). In our study, Bromus performance was poorest in the plant communities either with the greatest aboveground biomass or with belowground resource use patterns similar to Bromus. Centaurea performance was poorest in the plant communities dominated by a species with soil resource use patterns that were similar to Centaurea. These were not necessarily the most species rich or functionally diverse communities. The contrasting results from Centaurea and Bromus support the idea that the specific interaction between resource use patterns of an invader and the individual or combined components of a plant community are critical in determining the extent of invasion success (e.g., Dukes 2001, 2002; Fargione et al. 2003; Bakker and Wilson 2004; Brown 2004; Pokorny et al. 2005; but see Symstad 2000).

Many studies have shown that resource rich environments are more easily invaded than less fertile areas (Hobbs 1989; Rejmánek 1989; Huenneke et al. 1990; Burke and Grime 1996; Planty-Tabacchi et al. 1996; Stohlgren et al. 1998, 1999, 2002; Knops et al. 1999; Naeem et al. 2000; Davis and Pelsor 2001; Dukes 2001; Larson et al. 2001; Maurer and Zedler 2002; Bashkin et al. 2003; Fargione et al. 2003; Gross et al. 2005). In our study, site fertility did not dictate invader success, but relative community productivity and soil resource use patterns interacted to affect invader performance.

\section{Conclusion}

Alterations in resource availability can have large effects on plant communities over time and the implications of these shifts for natural plant communities should be studied further. Our results support the conclusions drawn by Levine et al. (2004) that biotic resistance may not be able to stop plant invasion, but can slow it down.
Our findings highlight the difficulty in basing generalizations regarding invasibility of communities on studies of a single site. Invader success in our study clearly depended upon site characteristics. Furthermore, we did not find the more fertile of the two sites to be any more easily invaded than the less fertile site. This discrepancy with landscape-scale and observational studies (e.g., Stohlgren et al. 1998, 1999, 2003) should be investigated further.

Overall, our results have implications for the conservation of biodiversity and restoration of communities and ecosystems. Encouraging the growth of species with a variety of resource use patterns through greater species and functional diversity may help reduce the success of a range of invasive plants at the local, neighborhood scale. These principles may be applied while designing plant communities for restoration to facilitate selection of species that will provide the greatest competitive barrier to recurrence or establishment of undesirable species. Understanding of the complex interactions between invasive species and native plant communities will also allow us to identify communities and ecosystems that are at high risk of being infested and altered by particular non-native species, and to detect the nonnative species most likely to have great impacts on particular communities and ecosystems.

Acknowledgments This work was funded by the California Department of Transportation Contract number F94TL10C. We extend our deepest thanks to J. H. Anderson, P. Beesley, D. Brown, A. Dyer, J. Gerlach, D. Gilpin, R. Gustavson, H. Haver, J. Haynes, T. Holmes, P. Kephart, J. McLean, J. Pfeiffer, C. Thomsen, J. Rusmore, M. Van Horn, C. Wardner, J. Wild, and others who provided assistance with field work, technical advice, field operation support and/or access to study sites. R. Hufbauer, A. Norton and their lab groups, D. Blumenthal, K. Lyons, R. Zimdahl and L. Perry provided valuable suggestions on earlier versions of the manuscript.

Open Access This article is distributed under the terms of the Creative Commons Attribution Noncommercial License which permits any noncommercial use, distribution, and reproduction in any medium, provided the original author(s) and source are credited.

\section{References}

Aarssen L (1997) High productivity in grassland ecosystems: effected by species diversity or productive species? Oikos 80:183-184. doi:10.2307/3546531 
Andrews W (1990) Soil survey of Yolo County, California. United States Department of Agriculture, Soil Conservation Service, University of California Agricultural Experimental Station, U.S. Government Printing Office, Washington, D.C.

Baker H (1965) Characteristics and modes of origin of weeds. In: Baker H, Stebbins G (eds) The genetics of colonizing species. Proceedings of the first international union of biological sciences symposia on general biology. Academic Press, New York

Bakker J, Wilson S (2004) Using ecological restoration to constrain biological invasion. J Appl Ecol 41:1058-1064. doi:10.1111/j.0021-8901.2004.00962.x

Bashkin M, Stohlgren T, Otsuki M et al (2003) Soil characteristics and plant exotic species invasions in the Grand StaircaseEscalante National Monument, Utah, USA. Appl Soil Ecol 22:67-77. doi:10.1016/S0929-1393(02)00108-7

Brown CS (1998) Restoration of California Central Valley grasslands: applied and theoretical approaches to understanding interactions among prairie species. Dissertation, University of California, Davis

Brown CS (2004) Are functional guilds more realistic management units than individual species for restoration? Weed Technol 18:1566-1571. doi:10.1614/0890-037X(2004) 018[1566:AFGMRM]2.0.CO;2

Burke M, Grime J (1996) An experimental study of plant community invasibility. Ecology 77:776-790. doi:10.2307/ 2265501

Davis MA, Pelsor M (2001) Experimental support for a resourcebased mechanistic model of invasibility. Ecol Lett 4:421428. doi:10.1046/j.1461-0248.2001.00246.x

DiTomaso JM, Kyser GB, Pirosko CB (2003) Effect of light and density on yellow starthistle (Centaurea solstitialis) root growth and soil moisture use. Weed Sci 51:334-341. doi:10.1614/0043-1745(2003)051[0334:EOLADO]2.0.CO;2

Dukes JS (2001) Biodiversity and invasibility in grassland microcosms. Oecologia 126:563-568. doi:10.1007/s00442 0000549

Dukes JS (2002) Species composition and diversity affect grassland susceptibility and response to invasion. Ecol Appl 12:602-617. doi:10.1890/1051-0761(2002)012[0602:SCA DAG]2.0.CO;2

Ehrenfeld JG, Kourtev P, Huang W (2001) Changes in soil functions following invasions of exotic understory plants in deciduous forests. Ecol Appl 11:1287-1300. doi:10.1890/ 1051-0761(2001)011[1287:CISFFI]2.0.CO;2

Elton CS (1958) The ecology of invasions by animals and plants. Chapman \& Hall, London

Enloe SF, Ditomaso JM, Orloff SB, Drake DJ (2005) Perennial grass establishment integrated with clopyralid treatment for yellow starthistle management on annual range. Weed Technol 19:94-101. doi:10.1614/WT-03-262R1

Fargione J, Brown CS, Tilman D (2003) Community assembly and invasion: a test of neutral versus niche processes. Proc Natl Acad Sci USA 100:8916-8920

Goodwin BJ, McAllister AJ, Fahrig L (1999) Predicting invasiveness of plant species based on biological information. Conserv Biol 13:422-426. doi:10.1046/j.15231739.1999.013002422.x

Gordon DR (1998) Effects of invasive, non-indigenous plant species on ecosystem processes: lessons from Florida.
Ecol Appl 8:975-989. doi:10.1890/1051-0761(1998)008 [0975:EOINIP]2.0.CO;2

Gordon DR, Rice KM (1992) Partitioning of space and water between two California annual grassland species. Am J Bot 79:967-976. doi:10.2307/2444905

Gross KL, Mittelback GG, Reynolds H (2005) Grassland invasibility and diversity: responses to nutrients, seed input, and disturbance. Ecology 86:476-486. doi:10.1890/04-0122

Grotkopp E, Rejmánek M, Vermeij F (2002) Toward a causal explanation of plant invasiveness: seedling growth and life-history strategies of 29 pine (Pinus) species. Am Nat 159:396-419. doi:10.1086/338995

Hickman JC (1993) The Jepson manual: higher plants of California. University of California Press, Berkeley

Hobbs RJ (1989) The nature and effects of disturbance relative to invasions. In: Drake JA, Mooney HA, di Castri F et al (eds) Biological invasions: a global perspective. Wiley, Chichester, pp 389-401

Huenneke LF, Hamburg SP, Koide R et al (1990) Effects of soil resources on plant invasion and community structure in Californian serpentine grassland. Ecology 7:478-491. doi: $10.2307 / 1940302$

Huntington GL, Wardlaw JC, Minno M et al (1981) The soil survey. University of California, Davis (campus and adjacent lands). Department of Land, Air and Water Resources, University of California, Davis, California

Huston MA (1997) Hidden treatments in ecological experiments: re-evaluating the ecosystem function of biodiversity. Oecologia 110:449-460. doi:10.1007/s004420050180

Kennedy T, Naeem S, Howe K et al (2002) Biodiversity as a barrier to ecological invasions. Nature 417:636-638. doi: 10.1038/nature00776

Knops JMH, Tilman D, Haddad NM et al (1999) Effects of plant species richness on invasion dynamics, disease outbreaks, insect abundances, and diversity. Ecol Lett 2:286-293. doi: 10.1046/j.1461-0248.1999.00083.x

Larson DL, Anderson PJ, Newton W (2001) Alien plant invasion in mixed-grass prairie: effects of vegetation type and anthropogenic disturbance. Ecol Appl 11:128-141. doi:10.1890/ 1051-0761(2001)011[0128:APIIMG]2.0.CO;2

Levine JM (2000) Species diversity and biological invasions: relating local process to community pattern. Science 288:852-854. doi:10.1126/science.288.5467.852

Levine JM, Adler PB, Yelenik SG (2004) A meta-analysis of biotic resistance to plant invasions. Ecol Lett 7:975-989. doi:10.1111/j.1461-0248.2004.00657.x

Lonsdale WM (1999) Global patterns of plant invasions and the concept of invasibility. Ecology 80:1522-1536

Loreau M, Hector A (2001) Partitioning selection and complementarity in biodiversity experiments. Nature 412:72-76. doi: $10.1038 / 35083573$

Lyons KG, Schwartz MW (2001) Rare species loss alters ecosystem function-invasion resistance. Ecol Lett 4: 358-365. doi:10.1046/j.1461-0248.2001.00235.x

Maurer DA, Zedler JB (2002) Differential invasion of a wetland grass explained by tests of nutrients and light availability on establishment and clonal growth. Oecologia 131:279-288. doi:10.1007/s00442-002-0886-8

Naeem S, Knops JMH, Tilman D et al (2000) Plant diversity increases resistance to invasion in the absence of 
covarying extrinsic factors. Oikos 91:97-108. doi: $10.1034 /$ j.1600-0706.2000.910108.x

Noble IR (1989) Attributes of invaders and the invading process: terrestrial and vascular plants. In: Drake JA, Mooney $\mathrm{HA}$, di Castri $\mathrm{F}$ et al (eds) Biological invasions: a global perspective. Wiley, Chichester, pp 301-313

Orians GH (1984) Site characteristics promoting invasions and system impact of invaders. In: Mooney HA, Drake JA (eds) Ecology of biological invasions in North America and Hawaii. Springer, New York, pp 133-148

Owenby JR, Ezell DS (1992) Climatography of the United States No. 81 monthly station normals of temperature, precipitation, heating and cooling degree days 1961-90 California. National Oceanic and Atmospheric Administration National Climatic Data Center, Asheville

Planty-Tabacchi A-M, Tabacchi E, Naiman RJ et al (1996) Invasibility of species-rich communities in riparian zones. Conserv Biol 10:598-607

Pokorny ML, Sheley RL, Zabinski CA et al (2005) Plant functional group diversity as a mechanism for invasion resistance. Restor Ecol 13:448-459. doi:10.1111/j.1526100X.2005.00056.x

Prieur-Richard A-H, Lavorel S, Grigulis K et al (2000) Plant community diversity and invasibility by exotics: invasion of Mediterranean old fields by Conyza bonariensis and Conyza canadensis. Ecol Lett 3:412-422. doi:10.1046/j.1461-0248. 2000.00157.x

Rejmánek M (1989) Invasibility of plant communities. In: Drake JA, Mooney HA, di Castri F et al (eds) Biological invasions: a global perspective. Wiley, Chichester, pp 369-388

Rejmánek M (1996) A theory of seed plant invasiveness: the first sketch. Biol Conserv 78:171-181. doi:10.1016/00063207(96)00026-2

Richardson DM, Rejmánek M (2004) Conifers as invasive aliens: a global survey and predictive framework. Divers Distrib 10:321-331. doi:10.1111/j.1366-9516.2004.00096.x

Roy J (1990) In search of the characteristics of plant invaders. In: di Castri F, Hansen AJ, Debussche M (eds) Biological invasions in Europe and the Mediterranean Basin. Kluwer, Dordrecht, pp 335-351
Smith MD, Knapp AK (1999) Exotic plant species in a C4-dominated grassland: invasibility, disturbance, and community structure. Oecologia 120:605-612. doi:10.1007/ s004420050896

Stohlgren TJ, Bull KA, Yuka O et al (1998) Riparian zones as havens for exotic plant species in the central grasslands. Plant Ecol 138:113-125. doi:10.1023/A:1009764909413

Stohlgren TJ, Binkley D, Chong GW et al (1999) Exotic plant species invade hot spots of native plant diversity. Ecol Monogr 69:25-46

Stohlgren TJ, Chong GW, Schell LD et al (2002) Assessing vulnerability to invasion by nonnative plant species at multiple spatial scales. Environ Manag 29:566-577. doi: 10.1007/s00267-001-0006-2

Stohlgren TJ, Barnett DT, Kartesz JT (2003) The rich get richer: patterns of plant invasions in the United States. Front Ecol Environ 1:11-14

Symstad AJ (2000) A test of the effects of functional group richness and composition on grassland invasibility. Ecology 81:99-109

Tilman D (1997) Community invasibility, recruitment limitation, and grassland biodiversity. Ecology 78:81-92

Tilman D (1999) The ecological consequences of changes in biodiversity: a search for general principles. Ecology 80: 1455-1474

Vitousek PM (1990) Biological invasions and ecosystem processes: towards an integration of population biology and ecosystem studies. Oikos 57:7-13. doi:10.2307/3565731

Vitousek PM, Walker LR, Whiteaker LD et al (1987) Biological invasion by Myrica faya alters ecosystem development in Hawaii. Science 238:802-804. doi:10.1126/science.238. 4828.802

Wiesner L (1989) Rules for testing seeds. Journal of seed technology. United States Department of Agriculture, Association of Official Seed Analysis, Artcraft printers, Bozeman

Young SL (2007) The effects of species diversity and soil water dynamics on the invasion by yellow starthistle (Centaurea solstitialis) into established California Central Valley plant communities. Dissertation, University of California, Davis 